\title{
Correction to: The impact of novel and traditional food bank approaches on food insecurity: a longitudinal study in Ottawa, Canada
}

\author{
Anita Rizvi ${ }^{1 *}$, Rania Wasfi ${ }^{1,2}$, Aganeta Enns ${ }^{1}$ and Elizabeth Kristjansson ${ }^{1}$ \\ Correction to: BMC Public Health 21, 771 (2021) \\ http://orcid.org/10.1186/s12889-021-10841-6
}

It was highlighted that the original article [1] contained an error in the Results section, subheading Descriptive statistics/ Frequency of food Bank use in the previous 3 months in the last sentence of the first paragraph. The sentence erroneously read " ... compared to $50.5 \%$ in wave $2,42.4 \%$ in wave 3 , and $27.440 .6 \%$ in wave 4." Instead of " ... compared to $50.5 \%$ in wave 2, $42.4 \%$ in wave 3 , and $40.6 \%$ in wave $4 "$. The original article has been updated.

\section{Author details}

'School of Psychology, Faculty of Social Sciences, University of Ottawa, 136 Jean-Jacques Lussier Pvt, Room VNR5015, Vanier Hall, Ottawa, Ontario K1N 6N5, Canada. ${ }^{2}$ Centre for Surveillance and Applied Research, Public Health Agency of Canada, Government of Canada, Ottawa, Canada.

Published online: 19 May 2021

\section{Reference}

1. Rizvi A, et al. The impact of novel and traditional food bank approaches on food insecurity: a longitudinal study in Ottawa, Canada. BMC Public Health. 2021;21:771. https://doi.org/10.1186/s12889-021-10841-6.

\footnotetext{
The original article can be found online at https://doi.org/10.1186/s12889021-10841-6.

*Correspondence: arizv036@uottawa.ca

${ }^{1}$ School of Psychology, Faculty of Social Sciences, University of Ottawa, 136 Jean-Jacques Lussier Pvt, Room VNR5015, Vanier Hall, Ottawa, Ontario K1N 6N5, Canada

Full list of author information is available at the end of the article
}

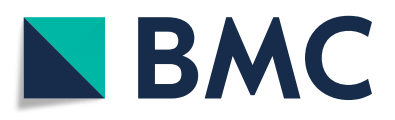

(C) The Author(s). 2021 Open Access This article is licensed under a Creative Commons Attribution 4.0 International License, which permits use, sharing, adaptation, distribution and reproduction in any medium or format, as long as you give appropriate credit to the original author(s) and the source, provide a link to the Creative Commons licence, and indicate if changes were made. The images or other third party material in this article are included in the article's Creative Commons licence, unless indicated otherwise in a credit line to the material. If material is not included in the article's Creative Commons licence and your intended use is not permitted by statutory regulation or exceeds the permitted use, you will need to obtain permission directly from the copyright holder. To view a copy of this licence, visit http://creativecommons.org/licenses/by/4.0/ The Creative Commons Public Domain Dedication waiver (http://creativecommons.org/publicdomain/zero/1.0/) applies to the data made available in this article, unless otherwise stated in a credit line to the data. 